\title{
Improvement of Tilapia (Oreochromis niloticus Linnaeus, 1758) Growth Performance Fed Three Commercial Feed Additives in Diets
}

\section{Adekunle Ayokanmi Dada*}

Department of Fisheries and Aquaculture Technology, Federal University of Technology, Akure, Ondo State, Nigeria

\begin{abstract}
An experiment was conducted to evaluate the effect of three commercial feed additives on growth, nutrient utilization, body composition and haematological profile of Nile tilapia Oreochromis niloticus fingerlings (average initial weight of 7.18-7.35 g). Three commercial feed additives Aqua booster ${ }^{\circledR}$ (Fish Vet, Inc. product, Ohio Dayton.), Aqua superliv ${ }^{\circledR}$ (Ayurvet Limited product, India) and Aqua pro ${ }^{\circledR}$ (Smart Microbial, Inc., USA) were added to the basal diet at $0.5 \mathrm{~g} / 100 \mathrm{~g}$ of feed additive respectively and fed to the fish for 56 days at $5 \%$ body weight. Fish fed on diets with commercial feed additives showed significantly improved growth performance, feed utilization and body composition compared to fish fed on the control diet. The best growth was observed in the group fed dietary Aqua superliv $^{\circledR}$ and the protein efficiency ratio was significantly highest in groups fed dietary Aqua booster ${ }^{\circledR}$ while specific growth rate was significantly highest in groups fed dietary Aqua superliv ${ }^{\circledR}$. The highest protein content $(70.87 \%)$ was obtained in the fish fed dietary Aqua pro® while the moisture content did not differ among treatments. Ash and lipid contents were significantly affected by feed additives. The results revealed that using Aqua superliv ${ }^{\circledR}$ at the level of $0.5 \mathrm{~g} / 100 \mathrm{~g}$ feed was the best in terms of weight gain $(8.85 \pm 0.92 \mathrm{~g})$ and feed utilization ( $F C R=0.26)$.
\end{abstract}

Keywords: Feed additives; Tilapia; Growth performance; Feed utilization

\section{Introduction}

Feed additives are substances which are added in minute amount into animal and aqua feeds and provides mechanism by which dietary deficiencies can be addressed which benefits not only in the nutrition but improves the growth rate of the animal or fish. Some of the most used growth-promoting feed additives in animal and aqua feeds are hormones, antibiotics, ionospheres and some salts.

There are large number of feed additives available to improve fish growth performance in the Nigeria markets and some of these additives used in feed mill are chemical products especially hormones and antibiotics which may cause unfavourable side effects. If growth performance and feed efficiency are increased in commercial aquaculture, the costs of productions are likely to be reduced.

World Health Organization encourages using of medicinal herbs and plants to substitute or minimize the use of chemicals through the global trend to go back to the nature. Attempts to use the natural materials such as medicinal plants could be widely accepted as feed additives to enhance feed utilization and aquaculture production.

Recently, some studies show the positive effects of dietary medicinal plants/herbs and feed additives on growth and feed utilization in fish and crayfish [1-8].

Nile tilapia (O. niloticus) is a well-known tropical food fish native to Africa. O. niloticus are principally herbivorous, although occasionally omnivorous. The fish is an efficient converter of waste foodstuff and appears to thrive well on artificial supplemental feed [9]. Tilapia farming is more acceptable, technically and economically more viable and sustainable. Tilapia culture is a profitable enterprise and even subsistence farmers in Nigeria can afford to culture tilapia to augment their income. Tilapia is consumed by poor people as it is relatively low priced commodity. Aquaculture requires high quality feeds which should contain not only necessary nutrients but also complementary feed additives to keep organism's healthy, faster growth and environmental friendly.
Over the years, the total world fishery production decreased slightly and the human consumption for aquatic products increased [10]. The reduction in capture fisheries was partly compensated for the fast growth of aquaculture industry. The need for enhanced disease resistance, feed efficiency, and growth performance of cultured organisms is substantial for various sectors of this industry [11]. The main objective of this study was to investigate the effects of using three commercial feed additives (Aqua booster ${ }^{\mathbb{R}}$; Aqua superliv ${ }^{\mathbb{R}}$ and Aqua pro $\left.^{\circledR}\right)$ on growth, feed utilization and body composition in Tilapia $(O$. niloticus) fingerlings.

\section{Materials and Methods}

\section{Formulation of experimental diets}

Commercial feed additives namely Aqua booster ${ }^{\mathbb{B}}$ (Fish Vet, Inc. product, Ohio Dayton.), Aqua superliv ${ }^{\circledR}$ (Ayurvet Limited product, India) and Aqua pro $^{\circledR}$ (Smart Microbial, Inc., USA) were purchased from a chemical store in Akure, Nigeria. Amounts of 0 (Control) and $0.5 \mathrm{~g} / 100 \mathrm{~g}$ of each of the additive were taken and mixed with a basal feed ( $30 \%$ crude protein), comprising fish meal, yellow maize, soybean meal, blood meal, fish oil, vegetable oil, vitamin premix and starch. All dietary ingredients were milled to a $3 \mathrm{~mm}$ particle size. The ingredients were thoroughly mixed in a Hobart A-2007 pelleting and mixing machine (Hobart Ltd, London, UK) to obtain a homogeneous mass and cassava starch was added as a binder. The resultant mash was then pressed without steam through a mixer with a $0.9 \mathrm{~mm}$ die. The pellets

*Corresponding author: Dada AA, Department of Fisheries and Aquaculture Technology, Federal University of Technology, Akure, Ondo State, Nigeria, Tel: 2348064364831; E-mail: dadaayokanmi@yahoo.com

Received January 25, 2015; Accepted February 09, 2015; Published March 15 2015

Citation: Dada AA (2015) Improvement of Tilapia (Oreochromis niloticus Linnaeus, 1758) Growth Performance Fed Three Commercial Feed Additives in Diets. J Aquac Res Development 6: 325. doi:10.4172/2155-9546.1000325

Copyright: (C) 2015 Dada AA. This is an open-access article distributed under the terms of the Creative Commons Attribution License, which permits unrestricted use, distribution, and reproduction in any medium, provided the original author and source are credited. 
were dried at ambient temperature $\left(27-30^{\circ} \mathrm{C}\right)$ and stored at $-20^{\circ} \mathrm{C}$ in a refrigerator. The diets were analysed for proximate composition, including crude protein, crude lipid, crude fibre, ash and moisture (Table 1).

\section{Experimental procedure}

12 (twelve) plastic tanks (52-litre), each half-filled with water were aerated continuously using air compressor. One hundred and twenty farm-raised $O$. niloticus fingerling siblings (with an average initial weight of 7.18-7.35 g) were acclimated to laboratory conditions for 14 days before distributed randomly into the twelve tanks (10 fish tank $\left.{ }^{-1}\right)$ representing three dietary treatments $(0.5 \mathrm{~g} / 100 \mathrm{~g}$ of feed additives) designated as DAB (aqua booster ${ }^{\mathbb{R}}$ ), DAP $\left(\right.$ aqua pro $^{\circledR}$ ) and DAS (aqua superliv $\left.^{\circledR}\right)$ respectively and a control (CTR) $(0 \mathrm{~g} / 100 \mathrm{~g}$ of feed additive). Fish were fed at $5 \%$ of their body weight (bw) per day in three equal meals, every five hours between 08:00 and 18:00. All fish were weighed and counted fortnightly and feeding rates were adjusted accordingly. At the end of the experimental period the following growth and feed utilization indices were calculated: weight gain (WG), specific growth rate (SGR), food conversion ratio (FCR) and protein efficiency ratio (PER) using the following formulae as described by Brown [12], Winberg [13], Castell and Teiws [14] and Miller and Bender [15], respectively.

\section{$\mathrm{WG}=$ final average weight $(\mathrm{g})$ - initial average weight $(\mathrm{g})$;

$$
\operatorname{SGR}(\% \mathrm{~d}-1)=100 \times(\ln W \mathrm{t}-\ln W 0) / t
$$

Where $W \mathrm{t}$ and $W 0$ represent final and initial body weights of fish, respectively, and $t$ represents the duration of the feeding trial;

FCR = dry weight of feed $(\mathrm{g}) /$ wet weight gain by fish $(\mathrm{g})$; and

PER = wet weight gain by fish $(\mathrm{g}) /$ protein intake $(\mathrm{g})$

Where protein intake $(\mathrm{g})=$ protein $(\%)$ in feed $\times$ total weight $(\mathrm{g})$ of diet consumed / 100.

Water quality parameters such as temperature, $\mathrm{pH}$ and dissolved oxygen concentration were routinely monitored in all tanks during the study period using mercury-in-glass thermometer, $\mathrm{pH}$ meter (Hanna H198106 model) and dissolved oxygen meter (JPP- 607 model). At the beginning and end of the feeding trial, pooled samples of 15 fingerlings were analysed for carcass composition using [16] procedures.

\section{Statistical analyses}

Analysis of variance (ANOVA) was used at 95\% significance level to test for significant differences between the various treatment means obtained for the growth, feed utilization and carcass composition. Tukey's multiple range tests was used to determine which pairs of the treatment means differed significantly [17].

\section{Results}

Mean water quality parameters during the experiment were: dissolved oxygen $5.20 \pm 0.48 \mathrm{mg} \mathrm{l}^{-1}, \mathrm{pH} 7.01 \pm 0.07$ and temperature $26.70 \pm 0.85^{\circ} \mathrm{C}$. There were improvements in the growth responses of fish fed on dietary feed additives. The fastest growth responses were obtained in the fish fed on dietary Aqua superliv ${ }^{\mathbb{B}}$ while the slowest growth was obtained in the fish fed the control diet (CTR) (Table 2). However, there were significant differences in growth performance across the different dietary feed additives.

There were greater improvements in the feed conversion ratio (FCR) of fish fed on dietary feed additives except those fed on Aqua pro $^{\circledR}$ which was not significantly different from the control fish. The average FCRs were 0.26 and 0.33 for fish fed on Aqua superliv ${ }^{\circledR}$ (DAS) and Aqua booster ${ }^{\circledR}$ (DAB) diets respectively. The PER was 1.46, 1.28 and 1.00 for the fish fed diets Aqua superliv ${ }^{\circledR}$ (DAS), Aqua booster ${ }^{\circledR}$ (DAB) and Aqua pro (DAP) respectively. Fish fed on dietary feed additives had a significantly $(p<0.05)$ higher protein content than fish fed the control diet. The protein content was 70.87, 64.68 and 63.55 for fish fed diets Aqua pro ${ }^{\circledR}$ (DAP, Aqua booster ${ }^{\circledR}$ (DAB), Aqua superliv ${ }^{\circledR}$ and CTR respectively. The same trend was also observed for ash and crude lipid contents. There were greater improvements in the ash and crude contents of fish fed on dietary feed additives. The body composition values are given in Table 3. The haematological parameters of $O$. niloticus (Table 4$)$ showed no significant differences $(p \geq 0.05)$ in all the haematological parameters measured at the end of the experiment.

\section{Discussion}

The results suggest that dietary feed additives promoted the growth of $O$. niloticus fingerlings. These results showed that feed additives enhance nutrient utilization, which is reflected in improved weight gain, FCR, PER and SGR. Generally, better feed conversion ratio values were obtained in all treatments, but the poorest occurred in control (Table 2). There were significant differences in the FCR among the treatments $(p<0.05)$. [7] reported that Aqua superliv ${ }^{\circledR}$ in diets promoted growth and feed conversion efficiency in Nile tilapia fingerlings. Similar results were reported for using two different commercial feed additives for Nile tilapia fingerlings [18]. [11] also reported that African catfish fingerlings fed on diets supplemented by commercial feed additive Biogen $^{\circledR}$ exhibited faster growth than those fed with the control diet. Similarly, Asian sea bass Lates calcarifer [19], striped snakehead [20], olive flounder Paralichthys olivaceus [6], tilapia Oreochromis niloticus [21] and rainbow trout Ichthyophthirius multifiliis [22] feed additives in diets promoted growth and feed efficiency. From a proximate composition point of view, feed additives increased the level of protein in O. niloticus. The body composition values obtained in this study were similar to those reported by $[8,18]$ using commercial feed additives. Survival of $O$. niloticus can be improved by feed additives supplementation. Therefore, this result will stimulate a series of studies on the utilization of these three commercial feed additives in diets for fishes.

\begin{tabular}{|c|c|c|c|c|}
\hline \multirow{2}{*}{ Ingredients } & \multicolumn{4}{|c|}{ Dietary treatments } \\
\cline { 2 - 5 } & CTR & DAB & DAP & DAS \\
\hline Menhaden fish meal & 15 & 15 & 15 & 15 \\
\hline Soybean meal & 45 & 45 & 45 & 45 \\
\hline Corn meal & 25 & 25 & 25 & 25 \\
\hline Vegetable oil & 6 & 6 & 6 & 6 \\
\hline Cod liver oil & 4 & 4 & 4 & 4 \\
\hline Vitamin-mineral premix & 3 & 3 & 3 & 3 \\
\hline Corn starch & 2 & 2 & 2 & 2 \\
\hline Aqua pro® & - & - & 0.5 & - \\
\hline Superliv ${ }^{*}$ & - & - & - & 0.5 \\
\hline Aqua booster & - & 0.5 & - & - \\
\hline & Proximate composition (\% DM) & & \\
\hline Crude protein & 31.88 .83 & 31.54 & 31.63 & 31.67 \\
\hline Crude lipid & 9.82 & 9.81 & 9.80 & 9.81 \\
\hline Ash & 11.34 & 11.23 & 11.32 & 11.27 \\
\hline
\end{tabular}

Vitamin premix - A Pfizer livestock product containing the following per $\mathrm{kg}$ of feed: $A=4500 \mathrm{I} . \mathrm{U}, \mathrm{D}=11252 \mathrm{I} . \mathrm{U}, \mathrm{E}=71 \mathrm{I} . \mathrm{U}, \mathrm{K} 3=2 \mathrm{mg}, \mathrm{B} 12=0.015 \mathrm{mg}$, panthothenic acid $=5 \mathrm{mg}$, nicotinic acid $=14 \mathrm{mg}$, folic acid $=0.4 \mathrm{mg}$, biotin $=0.04 \mathrm{mg}$, choline $=150 \mathrm{mg}$, cobalt $=0.2 \mathrm{mg}$, copper $=4.5 \mathrm{mg}$, iron $=21$ $\mathrm{mg}$, manganese $=20 \mathrm{mg}$, iodine $=0.6 \mathrm{mg}$, selenium $=2.2 \mathrm{mg}$, zinc $=20 \mathrm{mg}$, antioxidant $=2 \mathrm{mg}$

Table 1: Ingredient composition (g) and proximate composition (\% DM) of basal diet 
Citation: Dada AA (2015) Improvement of Tilapia (Oreochromis niloticus Linnaeus, 1758) Growth Performance Fed Three Commercial Feed Additives in Diets. J Aquac Res Development 6: 325. doi:10.4172/2155-9546.1000325

\begin{tabular}{|c|c|c|c|c|}
\hline \multicolumn{5}{|c|}{ Experimental diet } \\
\hline Parameter & CTR & DAB & DAP & DAS \\
\hline $\begin{array}{c}\text { Initial average } \\
\text { weight (g) }\end{array}$ & $7.35(0.29)$ & $7.19(0.08)$ & $7.34(0.42)$ & $7.18(0.84)$ \\
\hline $\begin{array}{c}\text { Final average } \\
\text { weight (g) }\end{array}$ & $13.24(0.82)$ & $14.83(0.74)$ & $13.24(0.35)$ & $16.03(0.83)$ \\
\hline $\begin{array}{c}\text { Final average } \\
\text { weight gain (g) }\end{array}$ & $5.89(0.74)$ & $7.64(0.82)$ & $5.90(0.31)$ & $8.85(0.92)$ \\
\hline SGR (\%/day-1) & $1.05(0.04)$ & $1.29(0.11)$ & $1.05(0.03)$ & $1.43(0.11)$ \\
\hline FCR & $0.47(0.12)$ & $0.33(0.64)$ & $0.49(0.14)$ & $0.26(0.04)$ \\
\hline PER & $0.98(0.15)$ & $1.28(0.13)$ & $1.00(0.03)$ & $1.46(0.14)$ \\
\hline Survival (\%) & $85.00(7.07)$ & $100.00(0.00)$ & $85.00(7.07)$ & $100.00(0.00)$ \\
\hline
\end{tabular}

Means in a given column with the same superscript letter were not significantly different at $p<0.05$. Values in parentheses are standard errors of means. SGR = specific growth rate, $\mathrm{PER}=$ protein efficiency ratio, $\mathrm{FCR}=$ feed conversion ratio

Table 2: Mean growth performance and feed utilization of $O$. niloticus fingerlings fed experimental diets for 56 days.

\begin{tabular}{|c|c|c|c|c|}
\hline \multicolumn{5}{|c|}{ Experimental diet } \\
\hline Composition (\%) & CTR & DAB & DAP & DAS \\
\hline Moisture & $3.68(0.30)$ & $3.85(0.32)$ & $3.24(0.09)$ & $3.84 \pm 0.39$ \\
\hline Ash & $14.68(0.57)$ & $12.85(0.25)$ & $11.57(0.35$ & $13.84 \pm 0.39$ \\
\hline Crude protein & $60.48(1.17)$ & $64.68(1.73)$ & $70.87(1.37)$ & $63.55(1.14)$ \\
\hline Crude lipid & $12.77(0.93)$ & $10.87(0.25)$ & $10.06(0.23)$ & $10.56(0.41)$ \\
\hline Crude fibre & $0.96(0.09)$ & $0.81(0.78)$ & $0.89(0.92)$ & $0.91(0.04)$ \\
\hline NFE & $6.96(0.98)$ & $5.23(3.42)$ & $3.3(0.79)$ & $8.68(0.62)$ \\
\hline
\end{tabular}

Means in a given column with the same superscript letter were not significantly different at $p<0.05$. Values in parentheses are standard errors of means.

Table 3: Chemical composition of whole body of $O$. niloticus fingerlings fed experimental diets (wet basis).

\begin{tabular}{|l|l|l|l|l|}
\hline \multirow{2}{*}{$\begin{array}{l}\text { Blood } \\
\text { parameter }\end{array}$} & \multicolumn{4}{|l|}{ Experimental diet } \\
\cline { 2 - 5 } & CTR & DAB & DAP & DAS \\
\hline $\mathrm{Hb}(\mathrm{g} / 100 \mathrm{ml})$ & $9.85(1.20)$ & $10.35(0.92)$ & $11.00(2.40)$ & $8.75(0.64)$ \\
\hline $\mathrm{PCV}(\%)$ & $29.50(2.94)$ & $31.50(2.12)$ & $31.00(4.24)$ & $27.50(2.12)$ \\
\hline W BC $\left(\times 10^{3} / \mu \mathrm{l}\right)$ & $6050(2001.13)$ & $6600(1697.05)$ & $7200(848.5)$ & $8300(2121.32)$ \\
\hline RBC $\left(\times 10^{6} / \mu \mathrm{l}\right)$ & $3.10(0.28)$ & $3.48(0.04)$ & $3.80(0.57)$ & $2.80(0.57)$ \\
\hline MCHC (\%) & $33.35(0.07)$ & $33.35(0.07)$ & $33.25(0.21)$ & $33.15(0.07)$ \\
\hline MCH (Pg) & $31.7(0.99)$ & $31.45(0.49)$ & $30.30(0.14)$ & $31.85(2.19)$ \\
\hline MCV (FL) & $94.50(2.12)$ & $94.20(1.98)$ & $91.00(0.84)$ & $93.30(0.99)$ \\
\hline Neutrophils (\%) & $55.00(2.83)$ & $65.50(2.12)$ & $65.00(9.89)$ & $61.50(0.71)$ \\
\hline Lymphocyte (\%) & $41.00(1.41)$ & $32.50(3.54)$ & $33.50(12.02)$ & $38.50(0.71)$ \\
\hline Eosinophils (\%) & $1.00(1.41)$ & $1.50(0.71)$ & $0.00(0.00)$ & $0.00(0.00)$ \\
\hline Monocytes (\%) & $0.00(0.00)$ & $0.50(0.71)$ & $1.50(2.12)$ & $0.00(0.00)$ \\
\hline
\end{tabular}

Means in a given column with the same superscript letter were not significantly different at $p<0.05$. Values in parentheses are standard errors of means. $\mathrm{PCV}=$ packed cell volume, $\mathrm{Hb}=$ haemoglobin estimation, $\mathrm{WBC}=$ white blood cell count, RBC=red blood cell count

Table 4: Haematological characteristics of Oreochromisniloticus fed experimental diets.

\section{Conclusion}

This study established the efficacy of Aqua booster ${ }^{\circledR}$, Aqua superliv ${ }^{\circledR}$ and Aqua pro $^{\circledR}$ feed additives as growth promoter in O. niloticus fingerlings. Fish farmers should therefore be encouraged to supplement these feed additives especially Aqua booster ${ }^{\circledR}$ and Aqua superliv ${ }^{\circledR}$ in fish diet. Future research should focus on the improvement of rearing technologies for different species of fish reared using feed additive as a feed supplement.

\section{References}

1. Soosean C, Marimuthu K, Sudhakaran S, Xavier R (2010) Effect of mangosteen (Garcinia mangostana L.) extracts as a feed additive on growth and hematological parameters of African catfish (Clarias gariepinus) fingerlings Eur Rev Med Pharmacol Sci 14: 605-611.

2. Deng J, An Q, Bi B, Wang QB, Kong L, et al. (2011) Effect of ethanolic extract of proplis on growth performance and plasma biochemical parameters of rainbow trout (Oncorhynchus mykiss). Fish Physiol Biochem 37: 959-967.

3. Farahi A, Kasiri M, Sudagar M, Soleimani Irael M, Zorriehzahra SMJ (2011) Effect of dietary supplementation of Melissa officinalis and Aloe vera on hematological traits, lipid oxidation of carcass and performance in rainbow trout (Oncorhynchus mykiss). Online J of Anim Feed Res 2: 1-5.

4. Dada AA, Oviawe NE (2011) The use of bitter kola Garcinia kola dry seed powder as a natural growth-promoting agent for African sharptooth catfish Clarias gariepinus fingerlings. Afr J Aquat Sci 36: 97-100.

5. Prasad G, Mukthiraj S (2011) Effect of methanolic extract of Andrographis paniculata (Nees) on growth and haematology of Oreochromis mossambicus (Peters). World J Fish Mar Sci 3: 473-479.

6. Cho SH, Lee S (2012) Onion powder in the diet of the olive flounder Paralichthys olivaceus: Effects on the growth, body composition, and lysozyme activity. J World Aquacult Soc 43: 30-38

7. Dada AA (2012) Effects of herbal growth promoter feed additive in fish meal on the performance of nile tilapia (Oreochromis niloticus L.). Egypt Acad J Biolog Sci 4: 111-117.

8. Dada AA, Olugbemi BD (2013) Dietary effects of two commercial feed additives on growth performance and body composition of African catfish Clarias gariepinus fingerlings. Afr J Food Sci 7: 325-328.

9. Omoregie E, Igoche L, Ojobe TO, Absalom KV, Onusiriuka KV (2009) Effect of varying levels of sweet potato (Ipomea batatas) peels on growth, feed utilization and some biochemical responses of the cichlid (Oreochromis niloticus). Afric $\mathrm{J}$ Food Agri Nutr and Dev 9: 700-712.

10. FAO (2012) State of World Fisheries and Aquaculture.

11. EL-Haroun ER, MA A, Goda S, Kabir Chowdhury MA (2006) Effect of dietary probiotic Biogens supplementation as growth promoter on growth performance and feed utilization of Nile tilapia, Oreochromis niloticus (L.). Aquacul Res 37 1473-1480.

12. Brown ME (1957) Experimental studies on growth. Physiology of fishes Academic Press, New York.

13. Winberg GG (1956) Role of metabolism and food Requirement of fishes Belorussian State University, Belarus.

14. Castell JD, Tiews K (1980) Standardization of Methodology in Fish Nutrition Research, Hamburg.

15. Miller DS, Bender AE (1955) The determination of net protein utilization by a shortened method. Brit J Nutr 9: 382-388.

16. AOAC (Association of Official Analytical Chemists). (1997) Official methods of analysis of AOAC Arlington, Virginia.

17. Zar JH (1984) Biostastistical Analysis. Prentice - Hall Englewood Cliffs, New Jersey, USA.

18. Abdelhamid E, Mohamed KA (2008) Effect of using probiotics as growth promoters in commercial diets for monosex Nile tilapia (Oreochromis niloticus) fingerlings.

19. Talpur AD, Ikhwanuddin Mhd (2012) Dietary effects of garlic (Allium sativum) on haemato-immunological parameters, survival, growth, and disease resistance against Vibrio harveyi infection in Asian sea bass, Lates calcarifer (Bloch) Aquacul 364 -365: 6-12.

20. Haniffa MA, Margaret IV (2014) Effect of dietary administration of the herba additive Phyllanthus niruri on growth performance and hematological changes in striped snakehead. World Aquac 45: 66-68.

21. Felicitta J, Arti Manju R, Ronald J, Sakthika T, Nagarajan R, et al. (2013) Effect of different concentrations of somephytoadditives (Allium sativa and Allium cepa) on growth, survival and hematological parameters in tilapia (Oreochromis mossambicus) juveniles.

22. Jaafar RM, Scov J, Kania PW, Buchmann K (2011) Dose dependent effects of dietary immunostimulants on rainbow trout immune parameters and susceptility to the parasite Ichthyophthirius multifiliis. J Aquac Res Development S3: 001. 